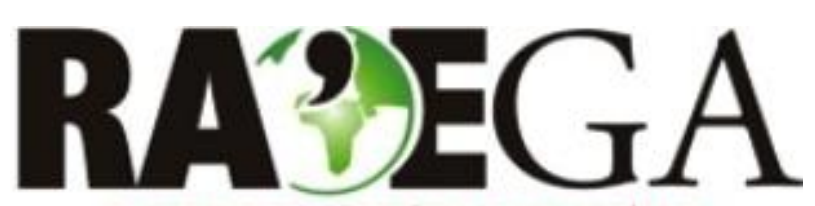

O ESPACYO GEOGRÁFICO EM ANÁLISE

\title{
TREZENA DE SANTO ANTÔNIO: UM PATRIMÔNIO IMATERIAL DA CIDADE DE CÁCERES, ESTADO DE MATO GROSSO, BRASIL
}

\author{
TREZENA OF SANTO ANTONIO: AN IMMATERIAL HERITAGE \\ OF THE CITY OF CÁCERES IN MATO GROSSO STATE, BRAZIL
}

\author{
Joliene da Silva Pereira \\ Laboratório de Geotecnologias - LABGEO \\ Universidade do Estado de Mato Grosso - UNEMAT \\ Cáceres, MT, Brasil \\ e-mail: jolienesilvapereira@gmail.com \\ Renato Fonseca de Arruda \\ Programa de Pós Graduação em Museologia e Patrimônio \\ Universidade Federal do Estado do Rio de Janeiro - UNIRIO \\ Rio de Janeiro, RJ, Brasil \\ e-mail: renatofonsc@gmail.com \\ Sandra Mara Alves da Silva Neves \\ Departamento de Geografia \\ Universidade do Estado de Mato Grosso - UNEMAT \\ Cáceres, MT, Brasil \\ e-mail:ssneves@unemat.br \\ Ronaldo José Neves \\ Departamento de Geografia \\ Universidade do Estado de Mato Grosso - UNEMAT \\ Cáceres, MT, Brasil \\ e-mail: rineves@unemat.br
}

Recebido em: 21/08/2015

Aceito em: 07/03/2016

\section{Resumo}

A Trezena de Santo Antônio é realizada na cidade de Cáceres no estado de Mato Grosso desde o fim da Guerra do Paraguai, do final do século XIX até os dias atuais. Diante dos aspectos históricos e culturais da Trezena, esta pesquisa teve como escopo investigar a organização da Trezena de Santo Antônio, analisando sua potencialidade enquanto patrimônio imaterial de Cáceres. A coleta dos dados foi viabilizada através de pesquisas de campo, 
bibliográfica e documental, explorando artigos, livros, monografias, dissertações, teses, jornais, fotografias, entre outras fontes. Obedecendo a um ciclo litúrgico e através de uma mistura do catolicismo erudito e popular, a celebração acontece anualmente através das rezas durante os treze primeiros dias do mês de junho, em que os participantes comemoram o Santo Antônio. São entoadas orações, rezas, ladainhas, preces, agradecimentos, cantos e encerrada as celebrações de devoção com a "missa solene" no dia de Santo Antônio, 13 de junho. Por fim, mesmo constituindo em um evento de circuito fechado, evidenciou-se que a Trezena possui potencial para ser patrimonializada como um patrimônio imaterial de Cáceres devido as suas características e importância para os devotos e participantes, configurando-se assim numa referência cultural que se mantem viva por mais de cem anos dada às esperanças manifestadas na fé comunitária.

Palavras-chave: Identificação; Referências Culturais; Salvaguarda do Patrimônio Cultural.

\begin{abstract}
The Trezena Santo Antonio is held the city of Cáceres in Mato Grosso since the end of the Paraguai war, the late nineteenth century to the present day. Considering historical and cultural aspects of Trezena, the objective of this research was to investigate of the organization the Trezena Santo Antonio, analyzing its potential as intangible heritage of Cáceres. Data collection was made possible through field research, bibliography and documents, exploring articles, books, monographs, dissertations, theses, newspapers, photographs, among other sources. Following a liturgical cycle and through a mixture of classical and popular catholicism, the celebration takes place annually through the prayers during the first thirteen days of June, when participants celebrate Santo. Antonio. They recite prayers, litanies, corners, acknowledgment and end the devotional celebrations with the "solemn mass" at Santo Antonio's Day, June 13. Even the Trezena constituting a closed circuit event, was evidenced it presents potential to be an intangible heritage of Cáceres due to their characteristics and importance to the devotees and participants, and has thus a cultural reference that keeps alive for over a hundred years given the hopes raised in the faith community.
\end{abstract}

Keywords: Identification; Cultural References; Safeguarding of Cultural Heritage.

\title{
1. INTRODUÇÃO
}

$\mathrm{Na}$ ciência geográfica são muitos os temas e as possibilidades para estudos no campo da Geografia Cultural, dentre eles destacam-se os voltados para as culturas populares, o cotidiano e o espaço. Nesse sentido, a religiosidade e a cultura são fenômenos que têm raízes na natureza social de 
produzir sentidos e estabelecer relações sociais dos indivíduos e são vistas como espaços de entendimento.

Das múltiplas manifestações religiosas da cultura brasileira, as mais vivenciadas pela sociedade são as em homenagem aos santos católicos. ${ }^{1}$ De acordo com JURKEVICS (2004), a devoção aos santos constitui-se

\begin{abstract}
numa das mais antigas práticas do cristianismo. Da veneração nos primeiros mártires cristãos aos nossos dias, o culto santoral sistematicamente ocupou um lugar de destaque, quer arraigado em antigas tradições, quer se renovando, se recriando para se adaptar a novos contextos (JURKEVICS, 2004, p. 11).
\end{abstract}

A devoção aos santos católicos constitui-se em um dos atos originários da igreja apostólica romana, que são estabelecidos através de datas comemorativas para os cultos e a dedicação ao sagrado. Segundo Menezes (2005, p. 27) "o culto aos santos revela-se útil para pensar as relações entre religião, cultura e sociedade”. Acrescenta-se também à economia e as relações de poder nas múltiplas sociedades.

Neste contexto, tais manifestações constituem-se em referências culturais que estão presentes e permeiam

\begin{abstract}
todos os lugares e atividades: nas ruas, em nossas casas, em nossas danças e músicas, nas artes, nos museus, escolas, igrejas, praças. Nos nossos modos de fazer, criar e trabalhar. Nos livros que escrevemos, na poesia que declamamos, nas brincadeiras que rezamos, nos cultos que professamos. Ele [as manifestações e práticas culturais] faz parte do nosso cotidiano, forma as identidades e determina os valores de uma sociedade. É ele que nos faz ser o que somos (IPHAN, 2013a, p. 3).
\end{abstract}

Com base no Instituto do Patrimônio Histórico e Artístico Nacional IPHAN (2013b), acrescenta-se que o registro das memórias, com intuito de salvaguardar as múltiplas manifestações culturais como patrimônio imaterial, contribui para valorizar as identidades dos múltiplos grupos sociais. Essa visão é um ponto de partida interessante, contudo, cabe reconhecer que é recente 0

\footnotetext{
${ }^{1}$ O censo de Demográfico de 2010 apresentou um crescimento na diversidade dos grupos religiosos, com maior pluralidade nas áreas mais urbanizadas e populosas. Mesmo seguindo a tendência de redução das últimas décadas, a proporção de católicos da Igreja Católica Apostólica Romana ainda permanece majoritária no Brasil, pois de 73,6\%, em 2000, para $64,4 \%$ (123.280.172 habitantes), em 2010, com queda de 9,2\% no percentual total de religiosos brasileiros (IBGE, 2010; NERI, 2011).
} 
empoderamento dessa visão acerca dos bens imateriais no âmbito das instituições responsáveis pela política de preservação do patrimônio cultural no Brasil (TELLES, 2007; SANDRONI, 2010), e ainda é pouco expressiva em relação a sua abrangência institucional e às múltiplas manifestações culturais existentes.

A preocupação institucional acerca da valorização dos bens culturais de natureza imaterial vem ocorrendo mais sistematicamente a partir da década de 1970, quando se passou a problematizar e reavaliar a preservação através do tombamento (até então o único instrumento de proteção) e a abrangência da política federal de preservação pelo IPHAN, instituídos na década de 1930. Havia uma lógica institucional que priorizava e privilegiava a materialidade e a monumentalidade dos bens em detrimento às manifestações culturais.

Para a salvaguarda do patrimônio imaterial enxergava-se a necessidade de "menos intervenção" e mais "identificação, reconhecimento, registro etnográfico, acompanhamento periódico, divulgação e apoio" (IPHAN, 2006, p. 19). Além disso, os bens culturais de natureza imaterial deveriam ser compreendidos a partir da ideia de continuidade histórica, e identificados através de estudos históricos e etnográficos que apontassem as características essenciais das manifestações, a sua manutenção ao longo do tempo e a tradição à qual se vinculam.

Em certa medida, o Decreto 3.551 de $2000^{2}$ preencheu em parte as limitações jurídicas institucional e estabeleceu a política nacional de patrimônio imaterial (PELEGRINI, 2008), sendo o patrimônio imaterial algo que:

\footnotetext{
é transmitido de geração a geração, constantemente recriado pelas comunidades e grupos em função de seu ambiente, de sua interação com a natureza e de sua história, gerando um sentimento de identidade e continuidade, contribuindo para promover o respeito à diversidade cultural e à criatividade humana. É apropriado por indivíduos e grupos sociais como importantes elementos de sua identidade. ${ }^{3}$
}

\footnotetext{
${ }^{2}$ BRASIL. Decreto № 3.551, de 4 de agosto de 2000. Institui o Registro de Bens Culturais de Natureza Imaterial que constituem patrimônio cultural brasileiro, cria o Programa Nacional do Patrimônio Imaterial e dá outras providências. Disponível em: <http://portal.iphan.gov.br/>. Acessado em: 05 abr. 2015.

${ }^{3}$ Patrimônio imaterial. Instituto do Patrimônio Histórico Artístico e Nacional (IPHAN). Online. Disponível em: <http://portal.iphan.gov.br/>. Acessado em: 05 abr. 2015.
} 
Em Mato Grosso, muitos bens culturais de natureza imaterial encontram-se identificados e reconhecidos em níveis municipais, estadual e/ou federal, como: a Festa de São Benedito, a Festança de Vila Bela da Santíssima Trindade, a Cavalhada de Poconé, a Festa de Sant'Ana, a Funeral Bororo, a Corrida de Toro de Buriti - Xavante, a Siriri, a Cururu, a Dança do Congo, a Dança dos Mascarados, a Pintura Corporal Xavante; o modo de fazer do Guaraná ralado, o modo de fazer da Arte Plumária Rikbatsa, o Futebol de Cabeça Paresí, entre outras. ${ }^{4}$

No município mato-grossense de Cáceres, área desta pesquisa, somente o Modo de Fazer da viola-de-cocho encontra-se registrado como patrimônio imaterial brasileiro (IPHAN, 2009, p. 19). Todavia, as suas manifestações religiosas da qual compõem o sistema de produção da Viola-decocho em Cáceres ainda não foram identificadas e inventariadas. Isso impõe dificuldades ao processo de reconhecimento, acompanhamento, promoção e valorização das manifestações e de seus detentores pelos órgãos municipal, estadual e/ou federal competentes.

Se considerarmos os processos históricos de constituição da cidade e suas manifestações culturais, nem mesmo a celebração alusiva ao seu santo padroeiro, São Luiz de Cáceres, conta com estudos sistematizados e difundidos regional e/ou nacionalmente. Em especial, estudos com enfoque na continuidade histórica das celebrações e associados às políticas culturais para os bens culturais de natureza imaterial, que muitas vezes são descontínuas e se restringem a listagem em calendários festivos municipal. ${ }^{5}$

\footnotetext{
${ }^{4}$ Exposição Patrimônio Imaterial Mato-Grossense. Museu de Arte e de Cultura Popular. Centro Cultural - UFMT. Universidade Federal de Mato Grosso, 17 março a 16 de abril, 2011.

${ }^{5}$ Informação identificada no site da Prefeitura Municipal de Cáceres, onde apresenta as celebrações apenas em um calendário de eventos. No único calendário encontrado, por exemplo, há referências as Festa de São Gonçalo, Novena, Missa Procissão, Folia de Reis, Festa de São Sebastião, Festa de Nossa Senhora de Aparecida, Santo Antônio, São Bento, São Pedro, N.S. Senhora do Carmo, São Lourenço, São Luiz, Mostra de Folclore Pantaneiro, Mostra Cultural de Siriri e Cururu, Festas Juninas etc. Entretanto, no âmbito das políticas culturais esses bens de natureza imaterial são tratados superficialmente seja como elementos da cultura cacerense, seja enquanto meio para a educação e/ou desenvolvimento turístico. Ver: Prefeitura divulga Calendário de Eventos para 2011. Online. Prefeitura de Cáceres, 19 de janeiro de 2011. Disponível em: <http://www.caceres.mt.gov.br/Noticia/974/prefeitura-divulgacalendario-de-eventos-para-2011\#.VcdRu_IVh3F>. Acessado em: 09/08/2015.
} 
Diante deste cenário que se escolheu a Trezena de Santo Antônio como objeto de estudo, considerando também as motivações culturais e profissionais dos pesquisadores, especialmente as decorrentes das observações supracitadas e de indagações relacionadas à dinâmica desta celebração religiosa em Cáceres.

Ao articular este estudo com a possibilidade do reconhecimento da Trezena de Santo Antônio de Cáceres, por meio das políticas culturais de natureza imaterial, observou-se que a "noção de continuidade histórica e o reconhecimento da dinâmica própria da transformação do bem imaterial [conduziriam] a proposição de uma ação fundamental: o acompanhamento periódico da manifestação para avaliação de sua permanência e registro das transformações e interferências em sua trajetória" (IPHAN, 2006, p. 19).

A Trezena de Santo Antônio de Cáceres constitui-se em uma das referências culturais (FONSECA, 2001; ARANTES, 2001) de abrangência majoritariamente local, no qual apresenta diferentes sentidos e valores para múltiplos grupos sociais da cidade. Trata-se de uma celebração religiosa carregada de significações, e em constante ressignificação, com "importância não somente para um indivíduo ou uma família" (IPHAN, 2013b, p. 5).

Nesta perspectiva, esta pesquisa teve como escopo investigar a organização da Trezena de Santo Antônio, analisando sua potencialidade enquanto patrimônio imaterial da cidade de Cáceres/MT. Com isso, busca-se subsidiar a identificação e o reconhecimento da mesma, considerando que tais ações também podem contribuir nas definições conceituais dos bens culturais, a sua institucionalização e a organização institucional das diferentes instâncias governamentais para a salvaguarda. Em especial, com respeito à dinâmica e salvaguardando as peculiaridades dos bens e os saberes dos detentores.

Espera-se também que o presente estudo acerca da celebração Trezena de Santo Antônio em Cáceres contribua para a produção de saberes que subsidiem e estimulem a proposição de ações de identificação, reconhecimento e valorização de modo a ir além da tradição da fé. Que esses saberes possam promover o respeito à diversidade cultural; a valorização da diferença; a ampliação do foco de ação do Estado; a ampliação do acesso ao 
patrimônio como direito de cidadania; e, que sejam observados enquanto vetor de desenvolvimento sustentável local.

\section{METODOLOGIA}

\subsection{Contextualização geográfica da área de estudo}

A fundação da cidade de Cáceres ocorreu à margem esquerda do rio Paraguai, estando situada entre as coordenadas geográficas de: $16^{\circ} 00^{\prime} 00^{\prime \prime} \mathrm{e}$ $16^{\circ} 07^{\prime} 10^{\prime \prime}$ de latitude Sul; e $57^{\circ} 43^{\prime} 10^{\prime \prime}$ e $57^{\circ} 37^{\prime} 30^{\prime \prime}$ de longitude Oeste (Figura 1). O município de Cáceres faz fronteira com a Bolívia, cuja população em 2010 foi quantificada em 87.942 mil habitantes, distribuídas em 24.351,408 $\mathrm{km}^{2}$ (IBGE, 2015). A população urbana é de 76.568 habitantes (IBGE, 2015), distribuídas em 43 bairros, que totalizam uma área territorial de $68,95 \mathrm{Km}^{2}$ (COCHEV et al., 2010).

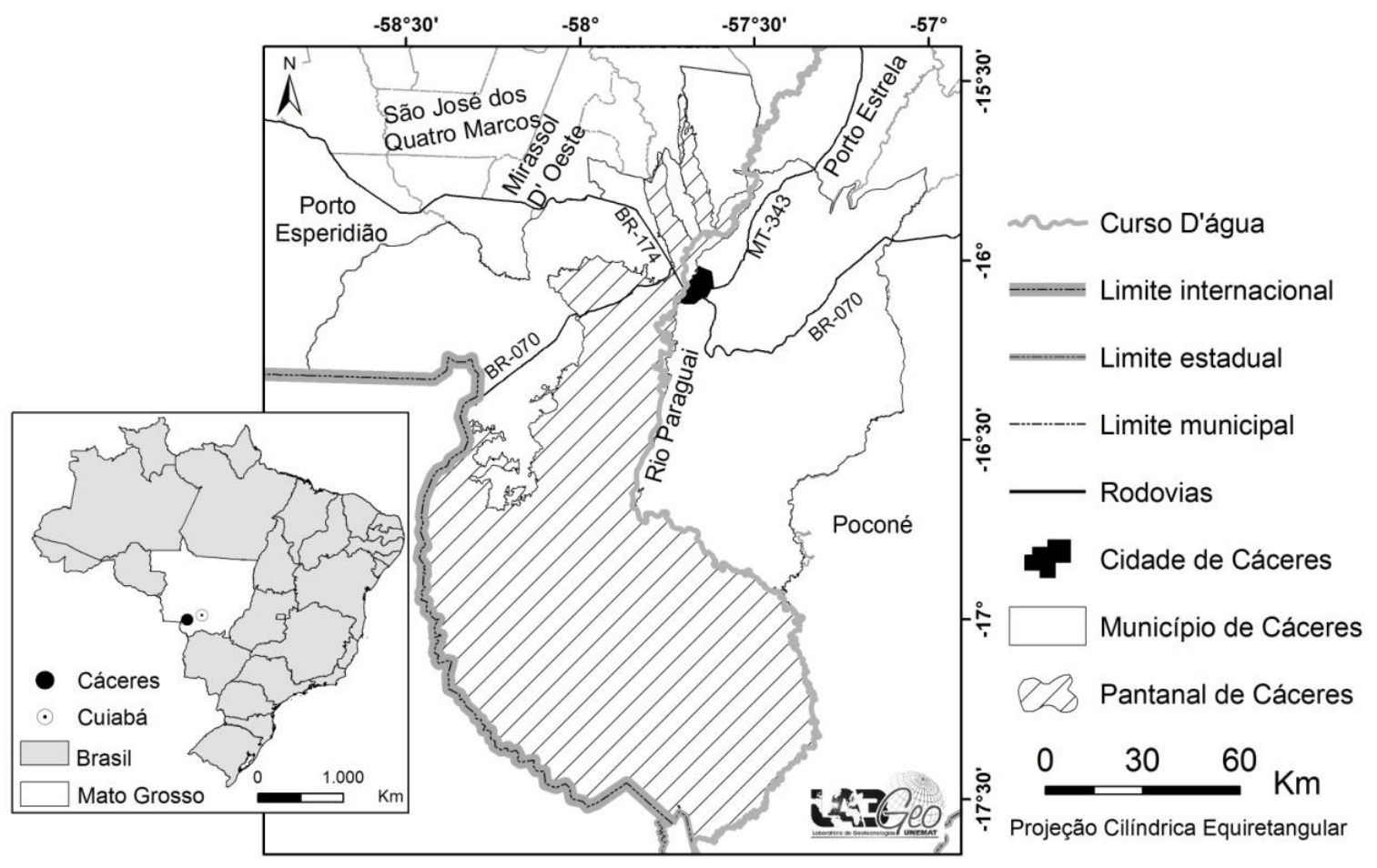

Figura 1: Situação de Cáceres no território brasileiro e em relação aos municípios vizinhos.

O processo histórico de consolidação da cidade de Cáceres está relacionado à ocupação institucionalizada em 06 de outubro de 1778, como vilarejo de Villa Maria, que surge mediante a pretensão da Coroa Portuguesa de ampliar os seus domínios sob a fronteira oeste; 


\begin{abstract}
fomentar a criação de novas rotas terrestres e fluviais que possibilitassem atender as exigências dos núcleos urbanos, surgidos na primeira metade do século XVIII (...); manter maior fiscalização e taxação da produção aurífera; além de estabelecer o controle diante de grupos poderosos que exerciam o poder à revelia do soberano português (...); e garantir, através da criação de núcleos urbanos, no oeste e sul do continente sul-americano, as áreas conquistadas frente aos espanhóis (CHAVES, 2011, p. 12;16-17).
\end{abstract}

No final do século XIX, após a Guerra do Paraguai, foi que devotos a Santo Antônio, residentes na cidade, passaram a realizar e celebrar anualmente a Trezena de Santo Antônio nos lares dos devotos residentes na área central da cidade de Cáceres.

\title{
3. PROCEDIMENTOS METODOLÓGICOS
}

Para a investigação da celebração da Trezena de Santo Antônio em Cáceres utilizou-se as técnicas de pesquisas bibliográfica, documental e de campo a fim de identificar os seus fenômenos e as relações entre eles.

$\mathrm{Na}$ elaboração dos instrumentos de coleta de dados foram utilizadas como referência as diretrizes estabelecidas no Manual de Aplicação (IPHAN, 2013b). Deste modo, dois formulários foram produzidos para as entrevistas, sendo um específico para os treze devotos organizadores, contendo doze perguntas, e o outro para 40 participantes da Trezena, constituído por onze questões.

A coleta geral dos dados ocorreu por meio da pesquisa de campo, no período de 10 de maio a 13 de junho de 2014, especificamente nos bairros: Centro (conjunto arquitetônico, urbanístico e paisagístico e seu entorno), Maracanãzinho, Cavalhada I e Cavalhada II. Na fase de preparação da Trezena realizou-se primeiramente o levantamento e acompanhamento nas residências das coordenadoras e organizadoras da Trezena, com a finalidade de identificar os devotos organizadores que disponibilizariam suas casas para realização das rezas da Trezena de 2014, as datas e os responsáveis pela execução da reza. O contato com os participantes, especialmente os devotos organizadores, para fins de agendamento das entrevistas (semiestruturadas) foi efetuado durante a Trezena. Nesta oportunidade utilizou-se a técnica de 
observação direta intensiva, norteada por um roteiro. As anotações foram efetuadas em caderno de campo, e considerando as contribuições teóricas de Barth (2000) e Fonseca (2001).

Durante os treze dias da Trezena ocorreram o acompanhamento, a observação e a anotação das diversas práticas culturais dos devotos. Houve a identificação das atividades da organização, dos papéis e vestimentas dos devotos, do sistema de captação dos recursos financeiros, do processo de elaboração da missa, além de comemorações, sorteios e o ato de caridade em prol da edificação do santuário de Santo Antônio em Cáceres ${ }^{6}$.

Foram entrevistados dois padres com a finalidade de compreender a relação e o papel da igreja na organização e desenvolvimento da celebração. Estabeleceu-se o contato com o padre da Paróquia Cristo Trabalhador e coordenador da edificação do santuário de Santo Antônio na cidade de Cáceres-MT, na perspectiva de obtenção de informações da Instituição em relação à celebração da Trezena. Para tanto, utilizou-se a técnica de entrevista, com registro das respostas do questionário preenchidas pelo entrevistado.

A sistematização das informações coletadas possibilitou a geração de estatísticas descritivas. Foi empregada a análise de conteúdo, visando à compreensão, a descrição e a análise qualitativa na perspectiva de obter e sistematizar o conhecimento acerca do objeto de estudo.

\subsection{Organização da Trezena de Santo Antônio em Cáceres/MT}

No território brasileiro as festividades católicas obedecem ao ano litúrgico ${ }^{7}$. O ciclo junino, de acordo com Vargas (2014), é marcado pelos festejos a Santo Antônio, São João e São Pedro comemorados, respectivamente nos dias 13, 24 e 29 de junho de cada ano.

A celebração de Santo Antônio é o primeiro evento do ciclo junino, constituído pela trezena (encontro para orações, realizados treze dias

\footnotetext{
${ }_{7}^{6}$ Iniciou em 2012 a construção do novo lugar de celebração denominado Santuário St. Antônio.

$7 \mathrm{O}$ ano litúrgico da Igreja Apostólica Romana gira entorno da unidade duração da vida de Cristo, correspondendo a eventos e episódios a ela ligados. O ano divide-se em "tempos/ ciclos litúrgicos a que correspondem festas fixas ou móveis, dependendo de estarem ou não relacionados a páscoa. Os tempos/ciclos litúrgicos são: Advento, Natal, Quaresma, Páscoa, Pentecostes e Tempo Comum" (PEREZ, 2010, 10).
} 
consecutivos), a missa e a procissão solene, cujas práticas são decorrentes de tradições europeias ligadas às manifestações populares que se enraizaram na cultura brasileira. Contudo, deve-se considerar que há diferentes doutrinas católicas europeias que se disseminaram, como a baseada no "catolicismo autoritário, tridentino e romanizador, que penetrou no Brasil na segunda metade do século XIX e se consolidou nas primeiras décadas do século $X X$, e o catolicismo tradicional vigente, de fortes raízes populares" (GAETA, 1997, p. 01).

No estado de Mato Grosso uma das comemorações de maior destaque alusiva ao Santo Antônio é feita no município de Barra do Garças. ${ }^{8}$ Em Cáceres, a Trezena é organizada por devotos em diversos bairros e assumiu lugar de destaque como manifestação religiosa local, especialmente no Centro da cidade e bairros circunvizinhos, quando passou a ser promovida pelo Coronel Antônio Aníbal da Motta ${ }^{9}$ em 1868, após o seu retorno de Corumbá com o fim da Guerra do Paraguai (GARCIA, 2011).

A devoção a Santo Antônio passa a compor de maneira mais sistemática o cotidiano de famílias da cidade após a Guerra do Paraguai, conforme relatos de três netas do Antônio Aníbal da Motta, quando após a promessa de devoção caso conseguissem ganhar a guerra ele foi presenteado com uma imagem de Santo Antônio no final do século XIX, na cidade de Corumbá (Figura 2 B). Estas relataram que o militar fez a promessa de realizar a Trezena até o último dia de sua vida.

No início a Trezena era realizada por poucas mulheres e crianças, reunindo parentes e amigos do circulo pessoal da família como forma de agradecimento pela vitória na batalha da Guerra do Paraguai, do dia treze de junho de 1867, data comemorativa do Santo Antônio, e que marcou a retomada da cidade de Corumbá e o impedimento da tomada de Vila Maria pelos

\footnotetext{
${ }^{8}$ Maior festa de Santo Antonio começa no interior de MT. COUTO, R. Olhar Direto. Cidades. Cuiabá/MT, 02 jun, 2011. Disponível em:<http://olhardireto.com.br/>. Acessado em: 05 abr.2015.

9 De acordo com Garcia (2011, 59), o "então coronel Antonio Aníbal da Motta, um dos comandantes militares que estavam em Corumbá quando do ataque paraguaio àquela vila, $\mathrm{e}$ que se retirou juntamente com as tropas brasileiras e parte da sua população civil em direção a Cuiabá, também ficou temeroso de que a ação dos paraguaios tivesse sequência, com a invasão de Vila Maria, onde residia a sua família".
} 
paraguaios. Após sua morte, a celebração continuou sendo promovida pela família, e também passou a envolver outros devotos e segmentos da igreja católica de Cáceres. No entanto, mesmo se estendendo para diversas classes sociais que ultrapassavam os militares e políticos que constituíam as relações entre as famílias e devotos, observou-se a permanência de processo de convite a famílias as quais são selecionadas por famílias e parte dos devotos.
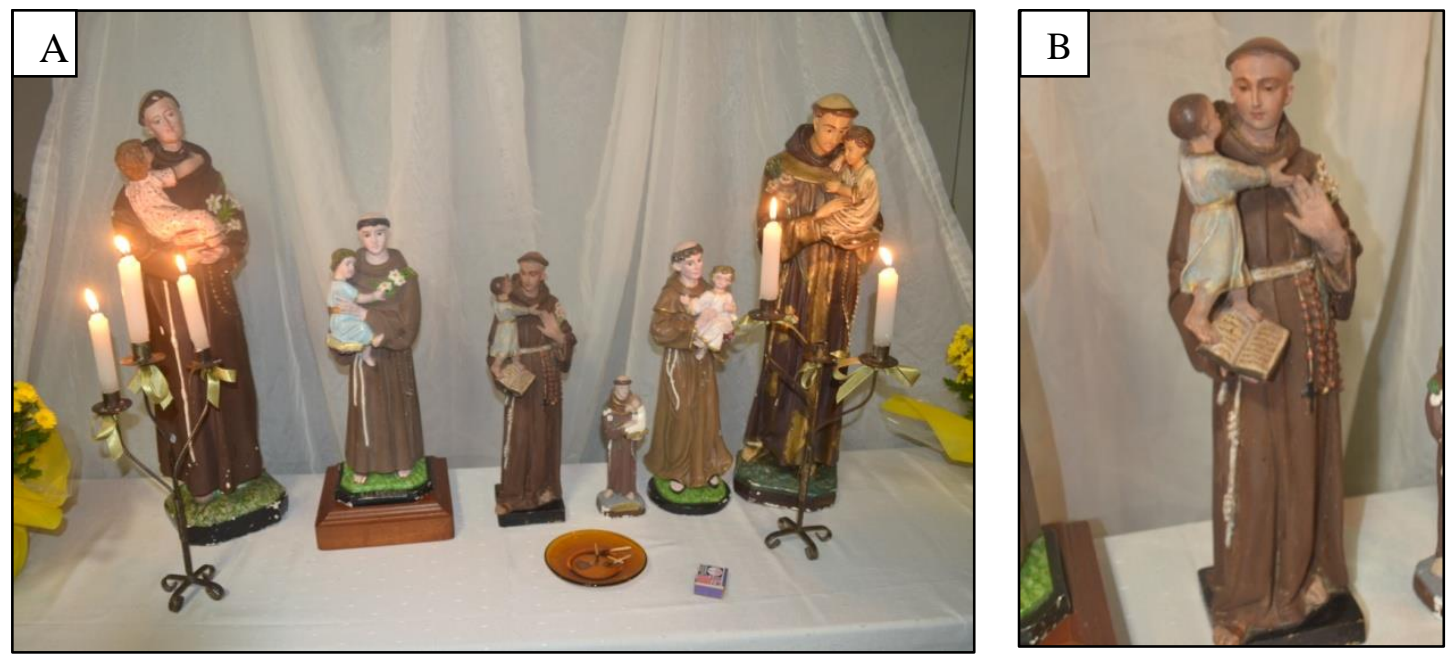

Figura 2. (A) Altar com as imagens de Santo Antônio. (B) Imagem de Santo Antônio que remonta ao final da Guerra do Paraguai. Foto: Pereira, 2014.

Com base em Pereira (2003), compreende-se a devoção popular como um "ato de dedicar-se ou consagrar-se a alguém ou à divindade (...). A devoção nasce, geralmente, da crença em determinados poderes sobrenaturais que o Santo de devoção possa ter, frequentemente um acontecimento extraordinário, milagre ou algo do gênero que ocorreu ou que se ouviu dizer que tenha ocorrido" (PEREIRA, 2003, 68).

Associada também ao período da história de consolidação da municipalidade de Cáceres, a Trezena de Santo Antônio contribui para vivificar o passado de um momento de vitória frente aos tempos de uma difícil guerra e ao mesmo tempo promove o sentimento de fé dos devotos, que almejam que seus novos pedidos sejam atendidos.

$\mathrm{Na}$ atualidade, identificou-se um fluxo relevante de participantes moradores de Cáceres na Trezena, mas houve os que se deslocaram de outros municípios da região, e até mesmo de outros Estados brasileiros. Dos 13 devotos organizadores que realizaram a Trezena no ano de $2014,87,50 \%$ eram naturais de Mato Grosso e, destes, 77,50\% nasceram em Cáceres. 
Outros $12,50 \%$ eram residentes na cidade, mas naturais dos estados de São Paulo, Santa Catarina, Ceará e Rio Grande do Sul.

No mesmo ano foram entrevistados 40 participantes, visando conhecer o tempo de participação na celebração, verificou-se que $18 \%$ frequentaram entre 1 a 5 anos; 23\% entre 5 a 10 anos; 23\% entre 11 a 15 anos; 10\% entre 16 a 20 anos; $15 \%$ entre 21 a 25 anos; e 13\% acima de 25 anos. Entre o total de entrevistados $92 \%$ são do gênero feminino e $8 \%$ do masculino.

De acordo com Saraiva e Sarmento (2008, p. 01) nas festas religiosas a participação feminina constitui a maioria. Situação que se repetiu na Trezena em Cáceres (Figura 3), considerando que foram elas que preparam e executaram cada dia de celebração, inclusive a organização da missa solene.
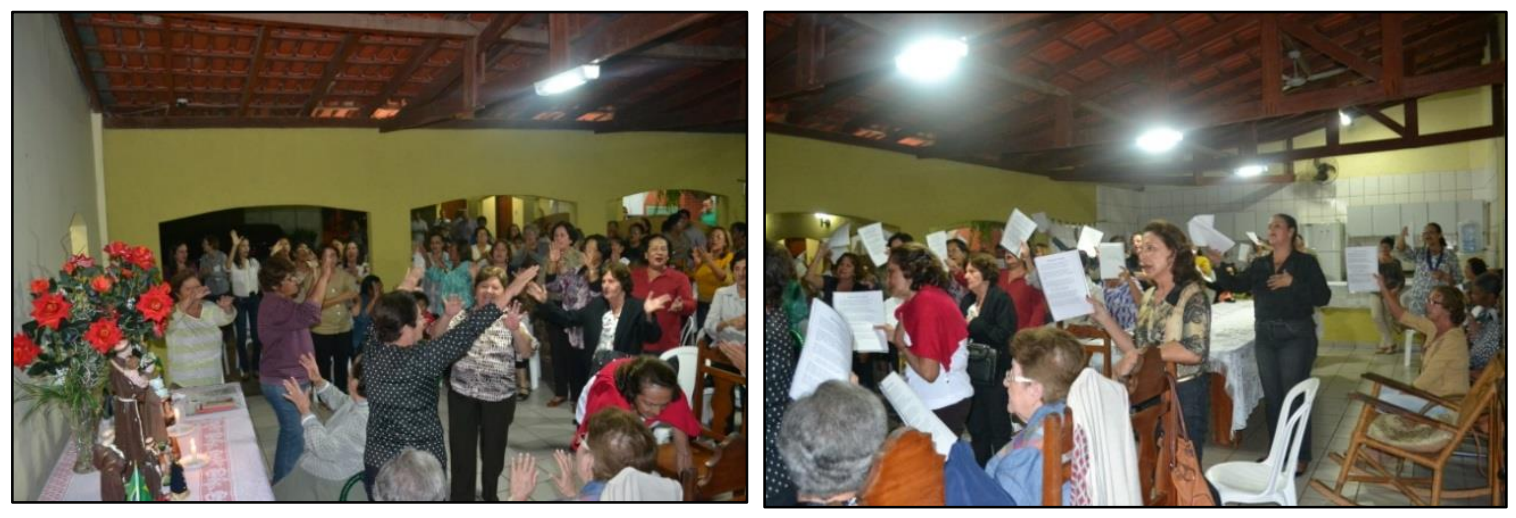

Figura 3. Predominância da participação feminina na Trezena em 2014. Fotos: Pereira, 2014.

No tocante a religião, o espaço da mulher além do trabalho e seu cotidiano eram regidos pelas atividades em torno da igreja, este foi um espaço além da família onde a mulher podia transitar sem maiores problemas, afinal a religião se tornou "afeminada" (WOODHEAD, 2002; DEL PRIORE, 2000), esta situação é observada com frequência nas celebrações da Trezena.

Todos os devotos organizadores da celebração encontram-se acima dos cinquenta anos, pois de acordo com o censo demográfico de 2010 (IBGE, 2015), a expectativa média de vida do brasileiro é de 75 anos. Esta informação ao mesmo tempo em que é relevante para compreender a promoção da Trezena, uma vez que é constituída em sua maioria por idosos, também é preocupante, considerando o processo de baixa adesão de jovens para dar continuidade da celebração. 
Segundo Vitorino e Vianna (2012, p. 137), a religiosidade e a espiritualidade também se "constituem em estratégias que os idosos utilizam em seu cotidiano, no sentido de buscar apoio para lidar com as situações estressantes, relacionadas à finitude, distância da família, contexto socioeconômico, diante dos problemas de saúde comuns do dia a dia".

Porém, mesmo sendo os idosos a maioria dos devotos organizadores identificou-se que há diversas motivações para participar da Trezena e acompanhar todos os dias da sua realização, partindo inclusive dos participantes devotos, os quais tiveram suas motivações pessoais. Para $42 \%$ dos entrevistados o significado é de tradição, fé, crença e união; 25\% religioso e cultural; $17 \%$ fé; $8 \%$ afirmaram que tem a função de disseminar 0 conhecimento da religião; e 8\% divulgar as bênçãos e graças recebidas.

A celebração da Trezena pode ser considerada uma tradição, reconhecendo que a tradição constitui-se numa prática "inventada", e em permanente ressignificação. ${ }^{10}$ No caso em questão, trata-se de uma prática decorrentes tanto da devoção ao Santo Antônio quanto da graça alcançada nos tempos da Guerra do Paraguai. No decorrer dos anos foi sendo ressignificada, quando também passou a ser concebida a partir da ideia de momento de união das famílias tanto dos organizadores, quanto dos participantes devotos. Para alguns familiares constitui-se numa oportunidade para se reencontrarem, conforme pode ser observado no depoimento de J. F. F. (77 anos) "Os meus filhos de Cuiabá todos ajudam. Todos os anos quem fazia as leituras era meu filho de Cuiabá. Mas este ano foi minha nora".

A organização da Trezena antecede um mês ao período de sua execução. Em 2014, o sorteio para definição dos devotos realizadores das rezas em suas casas ocorreu na residência de duas netas do Coronel, que

\footnotetext{
${ }^{10}$ Com isso, pode-se entender com base em Eric Hobsbawm (2002, p. 09-10), a "tradição inventada" como um conjunto de práticas, normalmente reguladas por regras tácita ou abertamente aceitas; tais práticas, de natureza ritual ou simbólica, visam inculcar certos valores e normas de comportamento através da repetição, o que implica, automaticamente; uma continuidade em relação ao passado. Aliás, sempre que possível, tenta-se estabelecer continuidade com um passado histórico apropriado (...). O passado histórico no qual a nova tradição é inserida não precisa ser remoto, perdido nas brumas do tempo. (...) Contudo, na medida em que há referência a um passado histórico, as tradições "inventadas" caracterizamse por estabelecer com ele uma continuidade bastante artificial. Em poucas palavras, elas são reações a situações novas que ou assumem a forma de referência a situações anteriores, ou estabelecem seu próprio passado através da repetição quase que obrigatória (...).
} 
moram juntas. Muitos devotos se dispuseram em ceder as suas residências para promover um dos dias da reza, inclusive sobrando casas. Observaram-se conflitos durante o processo de organização e ao logo da realização das rezas nas residências, inclusive alguns sem ir às rezas nas casas dos desafetos.

Os custos financeiros decorrentes dos preparativos de cada dia da Trezena recaíram a cada devoto que disponibilizaram suas casas, ou seja, além de ceder a casa também tiveram que custear com recursos próprios (ou encontrar meios colaborativos) os meios para organizar e preparar o encontro de reza. Após a execução da reza os presentes foram servidos com comidas típicas, tais como: paçoca de pilão ${ }^{11}$, carne seca com arroz, carne com mandioquinha, entre outros pratos. Segundo o representante da igreja, o padre M. A. P. (37 anos) o: "Oferecimento de comidas e bebidas, daquilo que se tem para servir constitui num gesto de atenção, de partilha, de agradecimento e de afeto (...) a esperança de que Deus acolha seu louvor, sua prece, seu desejo profundo de transformação".

Alguns devotos contaram com a colaboração de familiares e amigos que efetuam doações para que sejam adquiridos não apenas os alimentos, mas também as lembranças (réplicas em diversos tamanhos do Santo Antônio, mini-imagens de bolso, terços, medalhas, chaveiros, escapulários, agendas e livros), que foram sorteados aos participantes, que os guardam como lembrança da reza.

Houveram outras práticas ligadas à devoção muito significativas, como: pendurar uma figa ou cruz na porta, acender incenso, benzer-se ante uma igreja ou cemitério, guardar um amuleto no bolso ter um santo em casa. Isso tudo pertence ao universo religioso que protege cada um daquilo que ele crê que o ameaça (OLIVEIRA, 2010).

As casas são decoradas com flores em vasos, velas nos pires, castiçais, jarros, quadros de santo, escapulários e toalha de mesa geralmente de renda branca. De acordo com Ourives (2005, p. 93):

\footnotetext{
${ }^{11}$ Paçoca de Pilão: A paçoca de pilão trata-se do resultado de uma farofa temperada à base de farinha de mandioca com carne seca e os temperos tradicionais, que são misturados artesanalmente em um pilão.
} 
A fé faz com que o homem utilize diversos meios, para pedir proteção ao seu santo. Nesse vale tudo, velas, folhinhas, medalhas, escapulários e imagens são adquiridos com 0 objetivo de tê-los como escudos, contra diversos males e principalmente para conseguir alcançar diversas graças. Ter a imagem de um santo dentro de casa é motivo de alegria e principalmente de segurança, e nesse aspecto o homem deposita toda a sua fé na proteção do seu santo.

Embora, muitas pessoas tenham os objetos como amuletos de proteção e creem que fazem milagres, outros acabam adquirindo por pragmatismo sem muitas vezes acreditarem em suas significações (VEYNE, 2012). Com base em Barth (2002, p. 128), pode-se dizer que estas manifestações que permeiam essa celebração também são "distributivas" em relação à população, sendo muitas vezes "compartilhadas por alguns e não por outros".

Os participantes devotos utilizaram livros para seguir as rezas, possibilitando que desde o devoto assíduo ao iniciante acompanhassem a reza. Como 2014 foi o ano da Copa do Mundo em que Brasil foi sede e que Cuiabá, situada a $215 \mathrm{~km}$ de Cáceres, as casas receberam mudanças na decoração, foram inclusas bandeira do Brasil nos altares das residências, nas paredes e em alguns quintais bandeirolas.

A Trezena foi realizada do $1^{\circ}$ ao $13^{\circ}$ dias do mês de junho de 2014 , sendo que neste período as celebrações nas residências aconteceram à noite, iniciando sempre às $20 \mathrm{~h}$ e encerrando por volta das $23 \mathrm{~h}$. Todos os anos na abertura da Trezena acontecem a queima dos pedidos do ano anterior (Figura 4A), que são acondicionados num fundo falso do Santo Centenário, e a inserção de novos pedidos. Nos dias de reza não houve a presença de padre ou qualquer outra autoridade da igreja católica.

No primeiro dia de celebração, após a queima dos pedidos, ocorreu a entrada dos santos em procissão até o altar (Figura 4B), que vai se repetir nos demais doze dias, considerando que a reza ocorre em treze residências diferentes. Este momento segundo $45 \%$ dos participantes é tido como o mais admirado pelos devotos. 

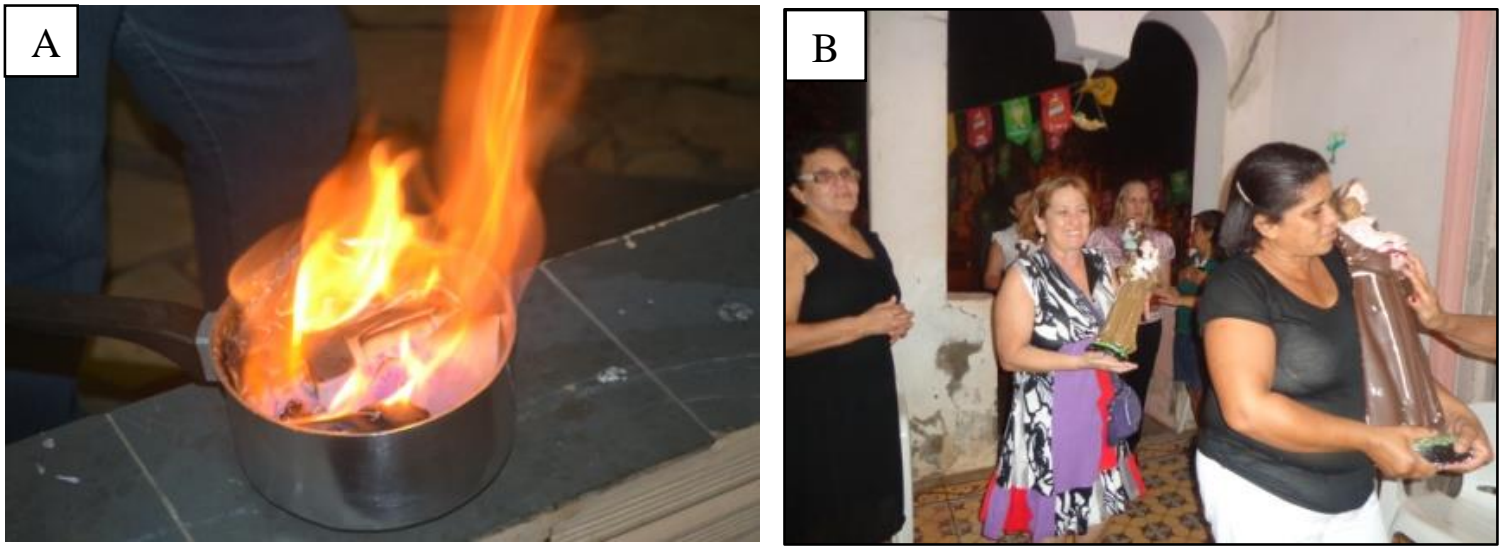

Figura 4. (A) Queima dos pedidos do ano de 2014. (B) Entrada dos santos na residência de uma das devotas. Fotos: Pereira, 2014.

$\mathrm{Na}$ sequência procederam-se as rezas, leituras, intensões e agradecimentos. São entoadas as ladainhas, cânticos, preces em intercessão à família, ao alimento e a melhoria da saúde dos doentes. Diferentemente dos anos anteriores solicitou-se a intercedência do Santo também pela seleção brasileira na Copa do Mundo e pela eleição de um bom Governante, uma vez que estava próxima às eleições de 2014. Segundo A. S. G. (58 anos), um dos organizadores, foi "Para rezar também pela Seleção brasileira".

No decorrer da reza ocorreram ainda encenações, sendo práticas pelas quais uma comunidade demonstra e comunica durante a música e a dança, gestos como mãos em direção ao alto, bater de palmas, bater na mesa, expressões orais frente ao altar. Segundo Taborda (1987, p. 82) "o gesto simbólico é o gesto pelo qual alguém expressa a outrem algum aspecto de sua relação com ele, como sociedade, com ou coisas, com Deus".

Em algumas residências foram utilizadas caixa amplificada, microfone e aparelho de DVD para auxiliar na celebração, devido ao número de pessoas presentes.

De acordo com $58 \%$ dos devotos organizadores as encenações e gestos são mais expressivos no ritual de entrada, quando é entoada a música "Glorioso Santo Antônio" (Domínio Público), afirmando a relação dos presentes com o Santo pós a finalização das rezas foi servido em todas as casas o jantar, e em algumas foi distribuído o "pão bento", que segundo a organizadora M. G. A. (64 anos) "é acondicionado nas latas de mantimentos durante 1 ano com a 
finalidade de que não falte nada em suas casas". Seguido do sorteio dos Santos, momento de descontração e confraternização da Trezena.

Devido à construção do Santuário de Santo Antônio, da paroquia Cristo Trabalhador, situada no bairro Santo Isabel, no ano de 2014 foi passado "o cofrinho" todos os dias entre os presentes na reza, visando levantar fundos. Os participantes se vestiram com camisetas de imagens do Santo, adquiridas junto à igreja, também para arrecadação em prol da edificação.

Para os devotos organizadores todos os dias de reza têm sua importância na renovação da fé, porém são distintos dos demais o dia 11 de junho, relativa ao aniversário de uma devota falecida, que realizou por muitos anos a reza em sua casa, e 13 de junho, dia da missa solene de encerramento da Trezena, devido ser o dia comemorativo do Santo Antônio. Observa-se que muitas vezes os traços históricos da devoção do Antônio Aníbal da Motta, por causa da Guerra do Paraguai, só aparecem quando os sujeitos se deparam com a necessidade da sua legitimação respaldada pela narrativa histórica, que muitas vezes é omitida diante das relações, pedidos e vivências do presente.

Para o pároco M. A. P. (37 anos) a "celebração da Trezena de Santo Antônio faz parte da vivência da devoção popular aos santos. É uma forma de expressar carinho, reconhecimento e gratidão ao santo no qual é devoto, e ainda suplicar a Deus uma graça que necessita alcançar mediante a intercessão do santo".

Contudo, dos 40 participantes entrevistados, 90\% deles vivenciaram a Trezena porque foram convidados e por devoção ao Santo Antônio. Para os familiares dos participantes que acompanharam a celebração a Trezena é de suma importância, seja por motivos de fé, religiosidade, graças alcançadas, bênçãos, devoção e união das famílias, associado ainda ao fato de que são católicos e ser a reza uma tradição de suas famílias. O que segundo o relato do padre M. A. P. (37 anos) pode ser atribuído "A Trezena faz parte também do encontro através da visita às familias, o acolhimento da melhor forma possível".

É pequena a participação dos jovens, mas 50\% dos entrevistados acreditam que estes darão continuidade a Trezena, pois é uma tradição que é passada de pai para filho. Outros $50 \%$ responderam que a cultura não é mais 
expressa do mesmo modo que há 10 anos, e que os jovens estão influenciados pelo modo de vida laico. Não somente os jovens como o restante dos participantes e que a fé esta sendo deixada de lado para vivenciarem apenas as confraternizações (festa).

Entretanto, a maioria dos inqueridos respondeu que a cada ano observa-se um aumento no número de participantes, constituídos por adultos. Há pessoas que ainda participaram ou frequentaram a celebração porque se sentiam como pertencentes a esse grupo cultural decorrente da participação efetiva de algum parente.

As manifestações e expressões culturais ocorrem de múltiplas maneiras. Conforme relato da participante O. L. C. (75 anos) "Sou devoto, eu peço para ele, e ele atende. Por todos os santos eu digo: Santos e santos do céu e da terra do mundo inteiro intercedei por nós. Assim eu peço”.

Para Peixoto (2007, p. 492-493) "Percebe-se que acredita e está mais próximo da presença de Deus, tem uma vida mais saudável. Supera de uma forma melhor tanto a vitória, no sair bem; e até mesmo a morte. Quem tem fé sabe exatamente o caminho de cada saída". Segundo o padre M. A. P. (37 anos) "os participantes acreditam que na presença da celebração possam implorar que Deus interceda por eles e que venha em seu auxílio, que atenda suas necessidades, que dê sentido ao seu existir, que socorra diante dos perigos e que mude algo em sua vida".

Na opinião dos participantes M. F. R. (45 anos) e D. C. M. (26 anos) a Trezena é "Muito importante, todos ficam na expectativa de chegar junho para participar. É onde encontramos os amigos que não vemos direto. $E$ onde acontecem os encontros da irmandade e na minha família". "É muito importante devido à fé e as graças alcançadas".

De acordo com o padre a relevância da Trezena é a de "unir grupos de famílias, agregar sentimentos, motivar e despertar as pessoas para a superação de sofrimentos, saindo do isolamento e do individualismo, mostrando a importância da fé comunitária, da necessidade de celebrar a vida no encontro com amigos, família e vizinhos motivados pelo exemplo do santo e a confiança na sua intercessão junto a Deus". 
Na visão da Igreja, essa Trezena de Santo Antônio realizada em casas de famílias não tem envolvimento direto da autoridade eclesiástica e não gera retorno material, pois este não é o objetivo, mas sim, revelar a importância de guardar a fé em Cristo, mantendo viva a tradição religiosa devocional ao Santo.

De acordo com o padre M. A. P. (37 anos) "A devoção popular está na raiz da formação cristã católica. Muitos participantes estão ligados ao cotidiano da igreja (paróquia), mas são livres para organizarem os encontros de orações na ocasião da proximidade do dia da celebração da festa de santo Antônio".

Os organizadores da Trezena de Santo Antônio não estavam envolvidos diretamente na construção do Santuário, mas estes acolhem as iniciativas pró Santuário, os eventos beneficentes e colaboram conforme seus anseios e possibilidades. Desta forma, considerou-se que, mesmo sendo negado pela autoridade eclesiástica, parece haver um retorno material e simbólico para a Igreja.

Diante da importância da identidade religiosa, histórica e cultural, para que a Trezena seja mantida e perpetuada os participantes afirmaram que é necessário incentivar os jovens, outras famílias e as pessoas a participarem. Para tanto, comentaram ser necessário à realização de reuniões entre os grupos, Irmandade, participantes e sociedade, envolvendo membros de Instituições, tais como: Prefeitura, Igreja e Universidade. Conforme relatos de M. L. (33 anos) "O incentivo a cultura. A própria Unemat é responsável pela história viva de um povo. Existe um grupo da irmandade para organizar a Trezena, os componentes são das famílias mais antigas de Cáceres. E até este ano, 2014 conseguiram realizá-la com êxito" e M. F. R. (45 anos) "Juntar mais a irmandade, fortalecer mais o grupo de Santo Antônio, organizar encontros entre todos. Porque tem gente que só vemos durante a Trezena”.

A participação na Trezena e a visão histórica da mesma transcendem o ato de devoção e se estendem para a construção e consolidação de relações de poder entre sujeitos com posições dominantes em muitas instituições da sociedade. Os encontros da reza também acabam servindo, portanto para construir laços e traçar estratégias de relações entre os sujeitos. 


\subsection{A Trezena de Santo Antônio: um patrimônio imaterial de Cáceres/MT}

Cidades históricas, a exemplo de Cáceres, mantém um padrão de transmissibilidade de saberes, práticas e valores religiosos fortemente influenciados pelo "sentimento de pertencimento, que sugere afeição, intimidade e influência na constituição da personalidade do indivíduo" (MARQUES, 2013, p. 30). Os múltiplos traços culturais das cidades podem ser utilizados para incentivar as novas gerações a continuarem a disseminar e praticar as suas manifestações culturais (ARRUDA et al., 2011).

No tocante aos bens culturais de natureza imaterial, conforme a Resolução do IPHAN 001/2006, ${ }^{12}$ os mesmos são "as criações culturais de caráter dinâmico e processual, fundadas na tradição e manifestadas por indivíduos ou grupos de indivíduos como expressão de sua identidade cultural e social". Estes, segundo o IPHAN, podem ser divididos em categorias conforme suas peculiaridades, quais sejam: Lugares, Celebrações, Formas de Expressão e Ofícios e Modos de Fazer.

O conhecer é o primeiro passo para "proteger" essas referências, pois é preciso antes de tudo identificá-las e enunciá-las (IPHAN, 2000, p. 14). O IPHAN (2006, p. 9) estabeleceu três instrumentos básicos de salvaguarda, conforme as particularidades dos bens culturais imateriais, sendo os mapeamentos e inventários de referências culturais; o registro, conforme formalizado no Decreto $3.551 / 2000$ e os planos e ações de salvaguarda, tais como incisos $1^{\circ}, 2^{\circ}, 3^{\circ}, 4^{\circ}$ e $5^{\circ}$ do Art. 216 da Constituição federal.

Para o mapeamento e inventário do bem imaterial, que é um instrumento que possibilita uma coleta ampla e sistematizada de dados, o IPHAN criou a metodologia denominada de Inventário Nacional de Referências Culturais - INRC (IPHAN, 2000), constituída pelas etapas de: levantamento preliminar, identificação e documentação. Constitui como uma característica imprescindível na metodologia de Inventário Nacional de Referências Culturais o "envolvimento e, mais que isso, a participação dos detentores, transmissores e usuários dos bens culturais, não apenas como informantes, mas também

\footnotetext{
${ }^{12}$ IPHAN. Resolução IPHAN no 1 de 03/08/2006. Publicado no D.O. em 23 de março de 2007. Determina os procedimentos a serem observados na instauração e instrução do processo administrativo de Registro de Bens Culturais de Natureza Imaterial.
} 
como intérpretes dos sentidos e valores atribuídos a esses bens e como agentes das ações de salvaguarda" (IPHAN, 2010, p. 21).

Nessa perspectiva, a Trezena de Santo Antônio possui potencial para ser concebida como patrimônio imaterial de Cáceres, uma vez que faz parte do cotidiano da cidade e seu conjunto arquitetônico, urbanístico e paisagístico, bem como mediante a sua importância para os devotos e participantes que a mantêm viva por mais de cem anos, com o mesmo perfil que mistura o culto erudito ao popular de seu início.

Para $83 \%$ dos participantes entrevistados, se a Trezena se tornasse patrimônio imaterial poderia trazer benefícios para a sociedade cacerense, conforme relatado pelo entrevistado I. M. L. S. (62 anos) "se tornaria evento cultural e faria parte do calendário das comemorações municipais".

Muitos devotos sabem a importância das políticas de patrimonialização como um meio de reconhecer, promover e disseminar as suas manifestações e a Trezena, mas sabem muito pouco sobre como proceder e os impactos das ações de salvaguarda. Embora atualmente haja possibilidades de se tentar a patrimonialização nas esferas federal e estadual ${ }^{13}$, em nível municipal inexiste uma política cultural que contemple sistematicamente os bens de natureza imaterial. Para tanto, além da necessidade da organização dos detentores também existem as ações de identificação e salvaguarda que requerem estudos prévios e complementares das referências culturais de modo a compreender a sua abrangência territorial e a importância social.

Em nível federal, a solicitação pode ser realizada por uma entidade ligada aos organizadores, considerando as peculiaridades da Trezena, a abrangência conceitual adotada e os instrumentos de identificação e salvaguarda do patrimônio imaterial. Há muitos bens de natureza religiosa patrimonializados, como em Chapada do Norte/MG, a comemoração em honra a Nossa Senhora do Rosário registrada na categoria de Celebrações, considerada fruto da devoção e da obrigação dos irmãos do Rosário para com a Nossa Senhora (MUNDIM, 2007).

\footnotetext{
${ }^{13}$ MATO GROSSO. Lei $\mathbf{N}^{\circ} \mathbf{9 . 1 0 7}$, de 31 de março de 2009. Dispõe sobre a proteção do Patrimônio Histórico, Artístico e Cultural do Estado de Mato Grosso e dá outras providências.
} 
A partir de três etapas estabelecidas na metodologia de Inventário Nacional de Referências Culturais, base da política federal, este estudo investigou os elementos inerentes ao levantamento preliminar, que visa a "reunião e sistematização das informações disponíveis sobre o universo a ser inventariado, a partir de pesquisa em fontes primárias e secundárias, produzindo-se, ao final desta etapa, um mapeamento cultural que pode ter caráter territorial, geopolítico ou temático" (IPHAN, 2006, p. 20). Assim, esperase ao disponibilizar informações que as mesmas possam contribuir para os diversos segmentos (sociedade, instituições públicas e gestão municipal) de modo a propor ações mais amplas de salvaguarda dos patrimônios imateriais de Cáceres e o reconhecimento do seu conjunto arquitetônico, urbanístico e paisagístico, tombado pelo IPHAN e pelo governo estadual, uma vez que o poder público municipal conta apenas com instrumentos jurídicos e institucionais de preservação dos bens materiais. ${ }^{14}$

No tocante aos bens imateriais, o Decreto federal $3551 / 2000^{15}$ instituiu o Registro dos bens culturais e o programa nacional de patrimônio imaterial, inspirando desde então governos estaduais e municipais a elaborarem legislações de salvaguarda do patrimônio cultural imaterial no âmbito de sua região (RAMASSOTE \& BESSON, 2010; SANT'ANNA, 2010). Porém, mesmo diante de todo processo de identificação, valorização e salvaguarda da década de 2000, ainda não conseguiu sensibilizar o poder público municipal de Cáceres de modo a criar, implementar e regulamentar a sua.

Para a execução do levantamento preliminar dos bens imateriais em nível federal, de acordo com a metodologia do INRC, é necessário à utilização de uma ficha que possui dois campos, um relativo à identificação e o outro a descrição. Quanto às informações pertinentes a identificação se faz necessário contemplar os seguintes itens: o nome mais comum do bem analisado, o que é o bem investigado, onde acontece, período importante ou momentos e datas

\footnotetext{
${ }^{14}$ BRASIL. Portaria n. 85, de 26 de junho de 2012. Diário Oficial [da] República Federativa do Brasil, Poder Executivo, Brasília, DF, 26 jun. Seção 1, n. 122, p. 23, 2012.

${ }^{15}$ BRASIL. Decreto n. 3.551 de 4 de agosto de 2000. Diário Oficial [da] República Federativa do Brasil, Presidência da República, Brasília, DF, 04 ago. 2000.
} 
importantes associadas, a história (origens e transformações ao longo do tempo) e seus significados para a sociedade.

$\mathrm{Na}$ descrição de um bem cultural são informadas a programação do evento ou suas etapas, pessoas envolvidas, comidas e bebidas especiais, roupas e acessórios específicos utilizados, expressões corporais, expressões orais, objetos importantes associados à celebração, estrutura e recursos necessários, outros bens culturais relacionados, e pôr fim a avaliação final, em que se podem indicar os pontos positivos e negativos para a sua continuidade, simultaneamente as recomendações que são nada mais que propostas para melhorar as condições de existência, realização e sua transmissão.

Face ao exposto, passar-se-á a relatar as informações relativas aos itens da identificação da celebração em estudo, em que se constatou que a mesma é conhecida pelos participantes e realizadores como Trezena de Santo Antônio, e concebida como uma celebração tradicional de devotos majoritariamente cacerenses.

A comemoração do Santo Antônio ocorre em diversos lugares do mundo, mas no contexto mato-grossense a Trezena realizada em Cáceres apresenta um arranjo peculiar devido às formas de organização que une visões eruditas e populares na celebração durante as práticas simbólicas, conforme já expostos. A data de realização da Trezena em Cáceres está associada à comemoração do Santo Antônio, que ocorre de $1^{\circ}$ ao $13^{\circ}$ dia do mês de junho de cada ano.

Na historicidade da Trezena, que trata de sua origem e transformações ao longo do tempo, verificou-se que seu início tem forte ligação com a retórica de "salvar a cidade" de uma suposta invasão paraguaia no século XIX. Fato este retratado na obra de Garcia (2011, p. 60), onde acrescenta que "o então Coronel Antônio Aníbal da Motta, vendo que a resistência seria vencida, junto a 12 soldados resolveram apelar para Deus, ou melhor, para o santo que consideravam o seu protetor, santo Antônio, que protegessem suas famílias".

Enquanto celebração, a Trezena apresenta um conjunto de valores humanos que, com o decorrer dos anos, tem sido transmitido cotidianamente pelos devotos. Conforme relata A. S. G. (58 anos) a significação é "religiosa, 
pois são vários dias para adorar orar. Tem a função de dar continuidade na cultura e na continuidade da fé".

Contempladas as informações pertinentes ao campo de identificação da ficha, constante na metodologia do INRC, sobreveio à investigação das informações relativas à descrição, conforme apresentadas a seguir.

A programação da celebração da Trezena é constituída por treze dias de adoração e louvor ao Santo nas residências dos devotos, conforme relatado no item anterior deste texto, sendo que no último dia é realizada uma missa solene na Paróquia de São Luiz de Cáceres.

Os participantes envolvidos na Trezena pertencem a grupos de atuação religiosa no município de Cáceres, tais como: a Irmandade Sagrado Coração de Jesus e Sagrada Família. Estas irmandades podem ser entendidas como uma associação, grupo ou confraria que se baseia em doutrinas ou preceitos religiosos, como por exemplo: Irmandade de Nossa Senhora do Carmo ou Irmandade Sagrado Coração de Jesus. Sendo as pessoas envolvidas na celebração advindas de outras cidades mato-grossenses e, até mesmo de outros Estados brasileiros, ultrapassando a fronteira geográfica municipal.

A preparação de comidas e bebidas especiais consumidas pelos participantes desta manifestação religiosa constitui-se em um momento peculiar que tem sido repassado de geração para geração. São servidos doces típicos, tais como, arroz doce, doce de mamão (Furrundu), doce de leite e de abóbora e bebida típica sem álcool de origem indígena denominada de aluá, e por fim os famosos o "pão bento", cuja responsabilidade de pôr fazê-los é do organizador devoto.

Souza Filho e Andrade (2012) ao investigarem a Festa do Divino, no município de Alcântara/MA e em Santa Teresa de Ávila, em Itamatatiua/MA constataram que as celebrações religiosas são muitas vezes entendidas pelos participantes como legítima parte do território. Na análise dos patrimônios imateriais dos Quilombolas, os autores op. cit. evidenciaram que os rituais de comensalidade, destacando os doces que são distribuídos aos presentes após as ladainhas. 
As manifestações católicas e as comidas, conforme Menezes (2014, p. 286), "constituem-se em uma das representações simbólicas mais autênticas da identidade cultural de uma população, identidade essa construída por "singularidades" que permeiam a história dos grupos sociais".

Nos dias de realização da Trezena não foi utilizada vestimentas especiais pelos organizadores e participantes, entretanto em 2014 alguns devotos vestiram camisetas em prol da edificação do santuário de Santo Antônio. Pertinente aos acessórios observou-se o uso de apostilas e livros para acompanhamento da reza.

Foram identificadas expressões corporais e encenações durante a realização da Trezena. Os gestuais identificados são semelhantes aos relatados por Maués (2000, p. 128) que investigou os devotos carismáticos de quatro paróquias católicas em Belém/PA, constatando que no decorrer da celebração os gestos mais característicos dos carismáticos "é fazer a oração com os braços erguidos e as mãos abertas, voltadas para frente". E o "hábito de, frequentemente, ao cantar, erguer as mãos e/ou tremê-las, num gesto característico, ou, ainda, agitá-las, de um lado para o outro do corpo".

$\mathrm{Na}$ Trezena foram presenciados principalmente os gestos de entrada da imagem centenária do Santo e nos momentos de louvor ao Santo durante a celebração. Dos objetos associados à celebração, o de maior importância para os devotos é a imagem centenária do santo, que foi presenteada ao Coronel Antônio Aníbal da Motta. Segundo Paiva (2014, p. 55-67) pode-se constatar uma "forte ressonância nessas relações entre devotos e objetos", onde também os devotos percebem os "objetos" como dotados de "forças" e "poderes". Fazem pedidos, levam ex-votos, ao estender a mão em direção aos "objetos", rezar diante de imagens consideradas "milagrosas", "oficiais".

Para realização da celebração a principal estrutura utilizada nos lares das famílias dos devotos organizadores são os altares visando à recepção da imagem do Santo. Sendo que em algumas residências houve a construção de altares fixos. Situação que, segundo Bittencourt (2011, p. 75) é comum, pois "normalmente nas casas há um pequeno altar sobre uma mesa de madeira, ornamentado com imagens de alguns santos, (...), tudo bem à vista a todos que 
chegam". Conforme Bittencourt (op. cit, p. 51), o intuito, mesmo que inconscientemente, é de demonstrar a quem chega à devoção religiosa presente naquela família, bem como, de "realizar as rezas individuais ou coletivas, (...), o altar é local de reafirmação da fé e da identidade que une o grupo de pessoas que diante dele se reúne para professar a sua fé e sua devoção religiosa".

$\mathrm{Na}$ atualidade tornou-se comum e necessário o uso de recursos audiovisuais, como caixa som amplificada, microfone e aparelho de som, e de doações financeiras para aquisição dos ingredientes para feitura dos pratos e das prendas para sorteio. Fato este decorrente do aumento da quantidade de participantes nas rezas e do poder aquisitivo dos devotos organizadores, evidenciando de certo modo a popularização da celebração.

A ornamentação dos locais de realização das rezas nas casas é simples, priorizando a forração das mesas dos altares com toalha branca, assim como é comum ocorrer nas igrejas católicas. Prioriza-se o altar por ser um "ponto de ligação entre o humano e o divino" e a cor branca da toalha por simbolizar a pureza (ROQUE, 2004, p. 11).

Nos treze dias de acompanhamento da Trezena foram identificados outros bens culturais associados a esta, como um conjunto de edificações patrimonializadas em níveis municipal, estadual e federal, marcando assim a forte relação entre trezena e o conjunto arquitetônico, urbanístico e histórico patrimonializado.

Ante ao exposto, compreende-se que a Trezena de Santo Antônio é uma celebração centenária que contribui para mantêm viva a tradição religiosa e a cultura popular de um coletivo de Cáceres. Ainda que não seja o único evento religioso alusivo ao Santo na municipalidade, constitui-se numa celebração que traz em si um caráter histórico muito importante para os seus detentores e a municipalidade. Destarte, observou-se também que a Universidade do Estado de Mato Grosso (Unemat) em parceria com outros segmentos sociais podem contribuir significativamente na geração de informações para o registro e patrimonialização dessa manifestação cultural. 


\section{CONSIDERAÇÕES FINAIS}

A investigação da organização da Trezena de Santo Antônio evidenciou que esta celebração faz parte do cotidiano e estimula a sociabilidade entre os atores sociais envolvidos por meio da fé e devoção ao Santo Antônio em Cáceres. A partir das informações geradas, tendo como referência os estudos teóricos das ciências humanas e os itens a metodologia do Inventário Nacional de Referências Culturais (INRC), evidenciou-se que essa manifestação religiosa apresenta potencialidade para configurar como patrimônio imaterial de Cáceres/MT.

Reconhecemos a incipiência da aplicação da lei de salvaguarda dos bens culturais em nível nacional e no território mato-grossense. Todavia, identificou-se pouca mobilização de autoridades do município de Cáceres de modo a reconhecer a importância de uma política municipal de preservação e salvaguarda das referências culturais de natureza imaterial. Considerando que para ser institucionalizada faz-se necessário a revisão da lei municipal de patrimônio de 1994, na qual abrange apenas os bens de natureza material.

Faz-se necessário ressaltar que este estudo contextualiza e analisa de forma preliminar a Trezena, enquanto referência cultural do município, sendo necessário um maior aprofundamento na pesquisa, a ser realizado por equipe multidisciplinar. E, com estudos voltados para compreender mais sobre a sua abrangência territorial e os impactos sociais, considerando que estes fatores constituem-se em elementos balizadores dos reconhecimentos pelas esferas estadual e federal.

\section{REFERÊNCIAS BIBLIOGRÁFICAS}

ARANTES, A. A. Patrimônio imaterial e referências culturais. Tempo Brasileiro, v. 1, n. 147, p. 129-139, 2001.

ARRUDA, R. F.; NEVES, S. M. A. S.; NEVES, R. J. Geotecnologias aplicadas no estudo do centro histórico de Cáceres, Mato Grosso - Brasil. GeoPantanal: revista do Curso de Geografia/ Universidade Federal de Mato Grosso do Sul. V. 6 , n. 11, p. 139-154, 2011. 
BARTH, F. A análise da cultura nas sociedades complexas. In: BARTH, F. O guru, o iniciador e outras variações antropológicas. Rio de Janeiro: Contracapa, 2000. p. 107-140.

BITTENCOURT, M. O. Santos e devotos: histórias de vida e devoções, em santo Antonio de Jesus - BA. 2011. 115f. Dissertação (Mestrado em História Regional e Local) - Universidade do Estado da Bahia, Antonio de Jesus/BA, 2011.

CHAVES, O. R. Império português: o marco de Jauru e a povoação fronteiriça de Vila Maria do Paraguai, século XVIII. In: CHAVES, O. R.; ARRUDA, E. F. (Orgs.). História e Memória de Cáceres, Cáceres: Editora UNEMAT, 2011. p. $11-35$.

COCHEV, J. S.; NEVES, S. M. A. S.; NEVES, R. J. Espaço urbano de Cáceres/MT analisado a partir de imagens de sensoriamento remoto e SIG. Revista GeoPantanal, v. 5, n. 9, p. 145-160, 2010.

DEL PRIORE, M. L. Festas e utopias no Brasil Colonial. São Paulo: Brasiliense, 2000.

FONSECA, M. C. L. Referências culturais: bases para novas políticas de patrimônio. Boletim de Políticas Setoriais. Brasília: IPEA, 2001.

FRANCIMÁRIO, V. S. INRC: breve discussão sobre o processo de avaliação da política de salvaguarda do IPHAN, a partir das ações de inventários de recorte territorial. In: Seminário internacional políticas culturais, 4, 2013, Rio de Janeiro. Anais... Rio de Janeiro: Fundação Casa de Rui Barbosa, 2013. Disponível em: <http://culturadigital.br/>. Acesso em: 01 jun. 2015.

FUNARI, P. P. A.; PEREGRINI, S. C. Patrimônio histórico e cultural. Rio de Janeiro: Jorge Zahar, 2006.

GAETA, M. A. J. V. A Cultura clerical e a folia popular. Rev. bras. Hist., v. 17, n. 34, p. 01-10, 1997.

GARCIA, D. S. C. Santo Antônio nos protegeu e a "Tapagem" impediu os paraguaios de invadir Vila Maria. In: CHAVES, O. R.; ARRUDA, E. F. (Orgs). História e Memória de Cáceres, Cáceres: Editora UNEMAT, 2011. p. 50 - 65.

HOBSBAWM, E.; RANGER, T. (Orgs.). A invenção das tradições. São Paulo: Paz e Terra, 2002. 
IBGE. Instituto Brasileiro de Geografia e Estatística (Ministério do Planejamento, Orçamento e Gestão). Censo Demográfico 2010 Características gerais da população, religião e pessoas com deficiência. IBGE: Rio de Janeiro, 2010.

IBGE. Cidades@. Disponível em: <http://www.cidades.ibge.gov.br/>. Acesso em: 10 abr. 2015.

IPHAN. Instituto Patrimônio Histórico Artístico e Nacional (IPHAN). Inventário nacional de referências culturais (INRC 2000): manual de aplicação. Brasília: Iphan, 2000. Disponível em: <portal.iphan.gov.br/>. Acesso em: 02 fev. 2015.

IPHAN. O Registro do Patrimônio Imaterial. Brasília: IPHAN/FUNARTE, 2006. Disponível em: <portal.iphan.gov.br/>. Acesso em: 03 fev. 2015.

IPHAN. "Modo de fazer da viola-de-cocho". Brasília: IPHAN, 2009. Disponível em: <portal.iphan.gov.br/>. Acesso em: 02 fev. 2015.

IPHAN. Os sambas, as rodas, os bumbas, os meus e os bois. 2 ed. Brasília: Iphan, 2010. Disponível em: <portal.iphan.gov.br/>. Acesso em: 02 fev. 2015.

IPHAN. Educação Patrimonial: manual de aplicação. Brasília: Iphan/DAF/ Cogedip/Ceduc, 2013b. Disponível em: <portal.iphan.gov.br/>. Acesso em: 05 fev. 2015.

IPHAN. Educação Patrimonial: Programa Mais Educação. Brasília: Iphan/ DAF/Cogedip/Ceduc, 2013a. Disponível em: <portal.iphan.gov.br/>. Acesso em: 02 fev. 2015.

JURKEVICS, V. I. Os Santos da Igreja e os Santos do Povo: devoções e manifestações de religiosidade popular. 2004. 229 f. Tese (Doutorado em História) - Universidade Federal do Paraná, Curitiba/PR, 2004.

MARQUES, A. A. A Identidade Cultural a Partir do Lugar: notas sobre Augé, Damatta e Hall. In: II CONINTER - Congresso Internacional Interdisciplinar em Sociais e Humanidade, 2., 2013, Belo Horizonte, MG. Anais... Belo Horizonte: UFMG, 2013, p. 1-10.

MAUÉS, R. H. Algumas técnicas corporais na renovação carismática católica. Revista Ciencias Sociales y Religión/Ciências Sociais e Religião, v. 2, n. 2, p. 119-151, set., 2000. 
MENEZES, R. C. Uma visita ao catolicismo brasileiro contemporâneo: a bênção de Santo Antônio num convento carioca. Revista USP, n. 67, p. 24-35, 2005.

MENEZES, S. S. M. Comida: identidade, tradição e cultura enraizada nas manifestações do catolicismo em Sergipe. Revista Ateliê Geográfico, v. 8, n. 2, p. 274-289, 2014.

MUNDIM, L. G. M. Festa de Nossa Senhora do Rosário dos Homens Pretos de Chapada do Norte: abordagens, ações e metodologias na salvaguarda do Patrimônio Imaterial. In: Simpósio nacional de História, 24., 2007, São Leopoldo, RS. Anais... São Leopoldo: Unisinos, 2007. p. 1-10.

NERI, M. C. Novo Mapa das Religiões. Rio de Janeiro: FGV/CPS, 2011.

OLIVEIRA, M. J. S. Desejo de continuar a ser vivo. Revista Último Andar: Caderno de Pesquisa em Ciências da Religião, v. 19, n. 2, p. 9-16, 2010.

OURIVES, P. A. Os Milagres de Santo Antonio Casamenteiro. 2005. $143 \mathrm{f}$. Monografia (Graduação em Comunicação Social) - Faculdade de Filosofia de Campos, Campo dos Goytacazes, 2005.

PAIVA, A. L. S. Quando os "objetos" se tornam "santos". Revista Textos Escolhidos de Cultura e Arte Populares, v. 11. n. 1, p. 55 - 70, 2014.

PEIXOTO, L. F. Tensão entre Fé e Razão. Revista Fragmentos de Cultura, v. 17, n. 3, p. 491-510, 2007.

PELEGRINI, Sandra C. A.. A gestão do patrimônio imaterial brasileiro na contemporaneidade. História [online]. vol.27, n.2, pp. 145-173, 2008.

PEREIRA, J. C. A linguagem do corpo na devoção popular do catolicismo. Revista de Estudos da Religião, v 3, n. 3, p. 67-98, 2003.

PEREZ, L. F. Passos de uma pesquisa nos passos das procissões lisboetas. CIES e-Working Papers (e-WP), n. 10, p. 1 - 23, 2010. Disponível em: <http://www.cies.iscte-iul.pt/>. Acesso em: 19 ago. 2015. 
RAMASSOTE, R. M.; BESSONI, G. Patrimônio Imaterial: ações e projetos da Superintendência do Iphan no DF. Arquitextos, São Paulo, ano 10, n. 120.00, Vitruvius, maio 2010.

ROQUE. M. I. R. Altar Cristão, evolução até à reforma católica. Lisboa: Universidade Lusíada Editora, 2004.

SARAIVA, A. L.; SARMENTO, S. S. O. Práticas devocionais e religiosidade popular: as mulheres ribeirinhas nos festejos religiosos de comunidades ao longo do rio Madeira. In: Simpósio Internacional Fazendo Gênero, 8., Florianópolis, 2008. Anais... Florianópolis: UFSC, 2008. p. 1-5.

SANDRONI, C. Samba de roda, patrimônio imaterial da humanidade. Estudos Avançados, v. 24, n. 69, p.373-388, 2010.

SANT'ANNA, M. A política federal salvaguarda do patrimônio cultural imaterial. IPEA: Desafios do desenvolvimento. Ano 7, Edição 62, 23 jul. 2010 - Edição Especial, 2010.

SILVA, P. S. O registro do patrimônio cultural imaterial e o inventário de bens culturais: as práticas do IPHAN e do IEPHA/MG. In: simpósio nacional de História, 27, Natal, 2013. Anais... Natal: UFRN, 2013. p. 1-17.

SOUZA FILHO. B.; ANDRADE, M. P. Patrimônio imaterial de quilombolas: limites da Metodologia de Inventário de Referências Culturais. Revista Horizontes Antropológicos, v. 18, n. 38, n. 38, p. 75-99, 2012.

TABORDA, F. Sacramentos, práxis e festa: para uma teologia latinoamericana dos sacramentos. Rio de Janeiro: Editora Vozes, 1987.

TELLES, M. F. P. O registro como forma de proteção do patrimônio cultural. Revista CPC, n 4, p.40-71, 2007.

VARGAS, M. A. M. Festas patrimônio: os ciclos junino e natalino de Sergipe. Revista Ateliê Geográfico, v. 8, n. 2, p. 252-273, 2014.

VEYNE, P. Condutas sem crença e obras de arte sem espectador. TOPOI, v. 13, n. 24, p. 175-188, jan./jun., 2012. 
VITORINO, L. M.; VIANNA, L. A. C. Coping religioso: espiritual de idosos institucionalizados. Acta paul. Enferm., v . 25, n. 1; p. 136-142, 2012.

WOODHEAD, L. Mulheres e Gênero: uma estrutura teórica. Revista de Estudos da Religião, v. 2, n. 1, p. 1-11, 2002. 